\title{
Recommendations for the management of pediatric septic shock in the first hour (part II)
}

\author{
Guillermo Kohn Loncarica, M.D. ${ }^{a}$, Ana Fustiñana, M.D. ${ }^{a}$ and \\ Roberto Jabornisky, M.D. ${ }^{b}$
}

\begin{abstract}
In 2016, the Surviving Sepsis Campaign and the National Institute for Health and Care Excellence (NICE) developed clinical practice guidelines for the management of pediatric septic shock. In 2017, the American College of Critical Care Medicine(ACCM) updated its recommendations for hemodynamic support of pediatric shock. Recognizing septic shock is critical, as well as an optimal, time-sensitive treatment. An adequate consultation with a pediatric specialist and / or a timely referral to a facility with a higher level of care are also critical for an appropriate outcome in the management of this condition. Here we analyze the bundles used in the management of these patients, which are essential to improve the quality of care.
\end{abstract}

Key words: patient care bundles, septic shock, pediatrics, sepsis.

http: / / dx.doi.org/10.5546/ aap.2019.eng.e24

To cite: Kohn Loncarica G, Fustiñana A, Jabornisky R. Recommendations for the management of pediatric septic shock in the first hour (part II). Arch Argent Pediatr 2019;117(1):e24-e33.

a. Emergency Department, Hospital "Prof. Dr. Juan P. Garrahan," Autonomous City of Buenos Aires.

b. School of Medicine, Universidad Nacional del Nordeste, Corrientes.

Argentina.

E-mail address:

Guillermo Kohn

Loncarica, M.D.:

gkohnloncarica@gmail. com

Funding:

None.

Conflict of interest:

None

Received: 11-18-2017

Accepted: 6-4-2018
In accordance with the SS diagnosis and treatment update, below we describe the resuscitation, stabilization, referral, and outcome measurement bundles for the management of septic shock at the emergency department before admission to the pediatric intensive care unit (ICU).

\section{RESUSCITATION BUNDLE General aspects}

Resuscitation is aimed mostly at correcting hemodynamic and metabolic alterations. This means improving oxygen delivery $\left(\mathrm{DO}_{2}\right)$ to the tissues and reducing its demand. $\mathrm{DO}_{2}$ depends on arterial oxygen content $\left(\mathrm{CaO}_{2}\right)$ and cardiac minute volume (CVM): $\mathrm{DO}_{2}=\mathrm{CaO}_{2} \times \mathrm{CMV}$. $\mathrm{CaO}_{2}$ depends on hemoglobin and oxygen saturation $\left(\mathrm{SaO}_{2}\right)$, while CMV depends on cardiac output and heart rate (HR). The cardiac output is determined by preload, myocardial contractility and afterload. The analysis of these variables helps to understand treatment targets. ${ }^{1-3}$

Recently, several organizations have updated their clinical practice guidelines for hemodynamic support in pediatric SS. Though recent studies conducted in adults have questioned goal-directed treatment, this is still suggested in the field of pediatrics. ${ }^{1,4,5}$

SS management starts at the recognition site (primary health care center, emergency department, hospitalization unit and/or ICU). Therefore, clinical practice guidelines for SS at the level of health care providers should be developed and published, similar to those for obstructive bronchial disease. ${ }^{6,7} \mathrm{~A}$ patient seen in a pre-hospital setting, where there is no possibility for a basic 
initial treatment, should be immediately and safely transferred to a hospital once SS is diagnosed. ${ }^{4}$

\section{Treatment goals}

These will depend on whether there is invasive monitoring available. Treatment should not be delayed due to a lack of invasive monitoring. Clinical, hemodynamic, and oxygenation goals are described below.

\section{Clinical goals ${ }^{1,5,8}$}

- Normalize HR for age.

- Normalize distal and central pulses.

- Normalize capillary refill.

- Normalize skin temperature.

- Normalize the sensorium.

- Optimize urine flow (>1 mL/ kg/h). Achieving these goals using stepwise treatments has reduced pediatric SS mortality by $40 \% .^{9}$

\section{Hemodynamic goals}

- Normalize tissue perfusion pressure (TPP)/ abdominal perfusion pressure (APP).

- Improve shock index (SI).

TPP and APP, which are overall indicators of blood flow, are priority measures at the ICU. They represent the difference between mean arterial pressure and central venous pressure or intra-abdominal pressure, respectively. The goal is to maintain normal pressure values for age (Table 1). ${ }^{10,11}$

At the emergency department, the SI [SI=HR / systolic blood pressure (SBP)] is more practical. The goal is to reduce the SI by lowering the HR and elevating the SBP..$^{12,13}$

\section{Oxygenation goals}

- Achieve oxygen saturation in the superior vena cava $\left(\mathrm{SaO}_{2 \mathrm{svc}}\right)>70 \%$. Oxygen saturation in the inferior vena cava $\left(\mathrm{SaO}_{2 \mathrm{ivc}}\right)$ or in the right atrium $\left(\mathrm{SaO}_{2 \mathrm{ra}}\right)$ is also valid. ${ }^{15}$
This is an overall tissue oxygenation indicator equivalent to mixed venous oxygen saturation $\left(\mathrm{SvO}_{2}\right) \cdot{ }^{16}$ It may be measured using specimens obtained from central venous catheters (CVCs) or implantable or semi-implantable catheters. Achieving this goal reduced mortality compared to groups where SBP normalization was the only priority. ${ }^{17,18}$

\section{Treatment (Figure 1)}

The organization of the treating team is critical and should encompass a coordinator and welldefined roles for other members, depending on available human resources. The following roles are recommended: 1) airway; 2) peripheral vascular access (PVA) and fluid administration; 3) drug preparation and infusion; 4) laboratory tests; 5) recording actions (deadlines and compliance with measures), and 6) family support and information.

Initial, basic, and universal goals include obtaining the following:

- A patent airway, with adequate oxygenation and ventilation.

- An adequate perfusion.

- Normal HR for age.

Actions should include the following:

- Recognize altered sensorium and perfusion.

- Maintain a patent airway and assess the need for endotracheal intubation (EI).

- Administer $\mathrm{O}_{2}$ (either through a mask, high-flow nasal cannula or mechanical ventilation).

- Establish at least 2 PVAs (or prepare implantable or semi-implantable catheters or intraosseous access).

- Begin non-invasive hemodynamic monitoring: serial measurement of blood pressure, pulse oximetry, continuous electrocardiogram, temperature, urine flow.

- Measure blood glucose and calcium.

TABLE 1. Heart rate and tissue perfusion/abdominal pressure thresholds for age

\begin{tabular}{|c|c|c|}
\hline & Heart rate (beats per minute) ${ }^{\mathrm{a}}$ & Tissue perfusion $/ \mathrm{abdominal}$ pressure \\
\hline Neonates ( $<30$ days $)$ & $110-160$ & MAP $[55+($ age $x 1.5)]-$ CVP or IAP $=55$ \\
\hline Infants ( 1 to 23 months old) & $90-160$ & $\operatorname{MAP}[55+($ age $x 1.5)]-\mathrm{CVP}$ or IAP $=58$ \\
\hline Children ( 2 to 7 years old) & $70-150$ & MAP $[55+($ age $x 1.5)]-\mathrm{CVP}$ or IAP $=65$ \\
\hline
\end{tabular}

MAP: mean arterial pressure; CVP: central venous pressure; IAP: intra-abdominal pressure.

a Acceptable thresholds for heart rate are defined by the Pediatric Risk of Mortality (PRISM) score.

$\mathrm{b}$ The target tissue perfusion pressure is based on the formula estimated for the $50^{\text {th }}$ percentile of MAP for a healthy child with the $50^{\text {th }}$ percentile for height and a CVP of $0 \mathrm{mmHg}$.

When CVP is $>0$, the target MAP should be adapted to the target of an adequate perfusion pressure.

Adapted from the American College of Critical Care Medicine. 
Once airway patency is warranted, and spontaneous breathing and circulation are confirmed, supplementary $\mathrm{O}_{2}$ should be given using a mask with reservoir bag or a high-flow nasal cannula to prevent both hypoxia and hyperoxia $\left(\mathrm{SaO}_{2} 100 \%\right){ }^{1,19}$
EI should be done if breathing work increases, cardiopulmonary insufficiency progresses (with bradycardia, bradypnea and hypotension) or the Glasgow score is $<8$. If possible, an adequate fluid preload and/or inotrope administration should be warranted in advance due to the frequent

FIGURE 1. Septic shock management algorithm. Adapted from the 2017 Consensus by the American College of Critical Care Medicine ${ }^{1}$

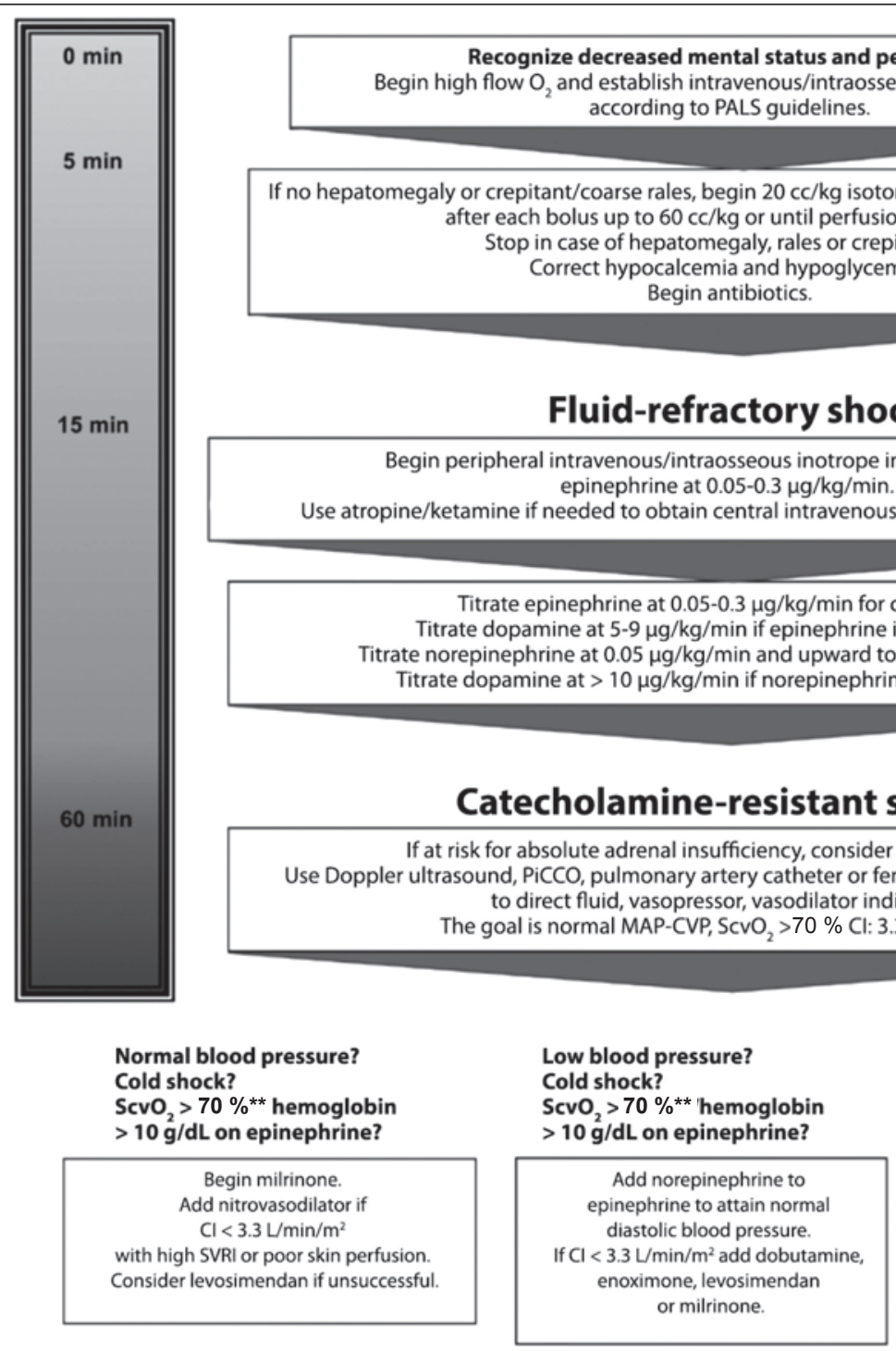

Persistent catecholamine-resistant shock?

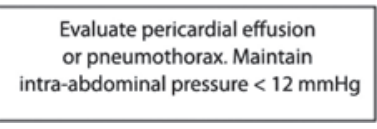

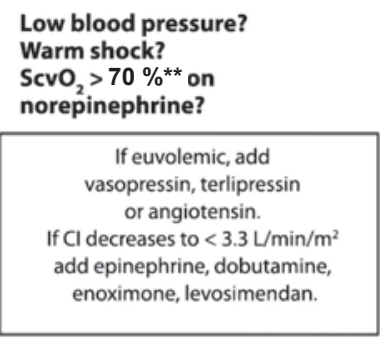

Refractory shock?

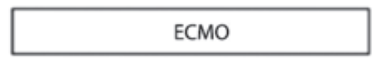

\footnotetext{
* It is suggested that each facility should have a diagnostic algorithm, perform a clinical control within 15 min in each patient with a positive screening, and start resuscitation in the first $15 \mathrm{~min}$.

** Except patients with congenital heart disease and mixed lesions.

PALS: Pediatric Advanced Life Support; $\mathrm{O}_{2}$ : oxygen; MAP: mean arterial pressure; CVP: central venous pressure; $\mathrm{ScvO}_{2}$ : central venous oxygen saturation; $\mathrm{CI}$ : cardiac index; ECMO: extracorporeal membrane oxygenation; PiCCO: pulse induced contour cardiac output; SVRI: systemic vascular resistance index.
} 
presence of relative/absolute hypovolemia and/ or myocardial dysfunction. Likewise, drugs used to facilitate EI may aggravate the hemodynamic problem. ${ }^{1}$

The preliminary results of a study conducted by the Latin American Society of Pediatric Emergency Medicine (Sociedad Latinoamericana de Emergencia Pediátrica, SLEPE) showed that $47 \%$ of emergency physicians decided to perform an EI in children with SS, even in the absence of respiratory insufficiency. ${ }^{20}$

PVAs are suggested to achieve the initial goals. If not possible after 5 minutes, an intraosseous access should be obtained -which is safe, easily placed, allows to administer drugs and fluids and collect lab specimens. ${ }^{21}$ An ultrasound may facilitate the placement of a CVC, but requires trained skills, equipment, and time. ${ }^{22,23}$

Lab specimens (blood calcium, blood glucose, blood count, liver and kidney function, lactic acid, coagulation profile, ionogram, and acid-base status) should be collected to correct alterations and identify multisystem involvement. ${ }^{1,4}$ The collection of specimens for cultures is recommended, but this should not delay antibiotic therapy. ${ }^{1,4}$

Non-invasive monitoring includes measuring respiratory rate, $\mathrm{HR}$, blood pressure, $\mathrm{SI}, \mathrm{SaO}_{2^{\prime}}$ urine flow, rectal and / or axillary temperature. These measurements should be often recorded in a sheet.

Then, the following should be done:

- Begin crystalloid boluses at $20 \mathrm{~mL} / \mathrm{kg}$ up to $40-$ $60 \mathrm{~mL} / \mathrm{kg}$ in 30 minutes. Control for volume overload signs after each bolus (hepatomegaly, rales, cough, and a third heart sound).

- Correct hypocalcemia and hypoglycemia.

- Give antibiotics.

- Begin and titrate vasoactive drugs via PVA or intraosseous access (if CVC is not available).

Fluid "bolus" resuscitation using 20-mL or 60-mL syringes is started immediately after obtaining a vascular access. This technique is preferred over a "continuous drip" and/ or infusion pump, which not always reach the necessary volume over an adequate time. After each bolus, the patient should be controlled for signs of volume overload, as mentioned above.

If shock signs are reversed or overload signs develop, fluid administration should be discontinued. In case of the latter or if $40-60 \mathrm{~mL} /$ $\mathrm{kg}$ are being administered without improvement, begin vasoactive drug infusion via a PVA or intraosseous access, if no CVC is available.
Volume resuscitation requirements may be $0 \mathrm{~mL} /$ $\mathrm{kg}$ if rales or hepatomegaly develop, although, in general, they are set at $40-60 \mathrm{~mL} / \mathrm{kg}$ initially. ${ }^{24}$

Infused volumes and administration duration should be controlled and recorded in a strict manner.

Crystalloid solutions are the first choice due to their low cost and high availability, although they show a greater incidence of electrolyte disorders and acute kidney injury and require higher volumes than colloid solutions. ${ }^{25-27}$

Balanced solutions (crystalloid solutions with a lower chlorine concentration) are an option but there are no studies indicating their superiority over traditional crystalloids. ${ }^{28-30}$

Colloids rapidly expand the intravascular space and stay there longer, but they are expensive, cause clotting alterations, and reduce ionic calcium with a negative inotropic effect, and there is no evidence indicating their superiority over crystalloids.

Children with complicated heart disease, prior heart failure or risk for cardiomyopathy (malnourished, history of myocarditis, cancer patients who are receiving or received anthracyclines) should begin fluids at $5-10 \mathrm{~mL} /$ $\mathrm{kg}$ over not less than 20 minutes, with frequent monitoring for overload signs. ${ }^{1,3}$

Peripheral edemas, typical of SS capillary lesions, are not always a synonym of hypervolemia or a contraindication to fluid administration. ${ }^{2}$

Although some authors propose a restricted fluid administration strategy, especially in facilities with a lower level of care, ${ }^{31}$ an "adequate" initial strategy and patient monitoring after each bolus are suggested. 1,4,32,33

Clinical practice guidelines recommend reaching fluid administration goals in the first 15 minutes, which, in practice, is hardly achievable. The SLEPE conducted a survey that showed that $56 \%$ of respondents achieved fluid administration goals over 30-60 minutes, and $37 \%$, in less than 30 minutes. ${ }^{20}$ Sankar et al., observed that bolus administration in less than 10 minutes showed greater risks for EI than administration over 15-20 minutes. ${ }^{34} \mathrm{~A}$ limit of 30 minutes is suggested as a more reasonable goal.

Antibiotic administration in the first hour improves the clinical course and reduces mortality due to $S S . .^{35-39}$ Initial empiric antibiotic regimes should consider the source of infection and be adequate by 48 or 72 hours of receiving the corresponding culture results. Antibiotic choice 
should be based on the most likely presumed infectious agent, the type of host, his/her age, nosocomial or community acquisition, and institutional epidemiology; the one with the lower toxicity and cost should be chosen.

Metabolic alterations may worsen the condition. A lack of intracellular glucose worsens energy failure. An anion gap $>16 \mathrm{mEq} / \mathrm{L}$ suggests glycopenia. To prevent glycopenia and improve glucose intake, $10 \%$ dextrose solutions at $4-6 \mathrm{mg} / \mathrm{kg} / \mathrm{min}$ are recommended, so as to maintain blood glucose levels between 80 and $150 \mathrm{mg} / \mathrm{dL} .{ }^{1,5}$ Hyperglycemia is also harmful. Blood glucose levels $>178 \mathrm{mg} / \mathrm{dL}$ double the risk for death in children with SS. ${ }^{40}$ In case of blood glucose $>150 \mathrm{mg} / \mathrm{dL}$, insulin administration should be started. ${ }^{1}$

Hypocalcemia should be corrected as per usual practice due to the effects of calcium on inotropism. ${ }^{1}$

Bicarbonate should not be given to patients with SS and $\mathrm{pH}>7.15$ because it is associated with sodium overload, volume overload, increase in serum lactate and partial pressure of carbon dioxide, and ionic calcium reduction. ${ }^{41,42}$

Vasoactive drugs are indicated subsequently. The impossibility to place a CVC, mostly due to the user's inexperience, is a barrier for the early administration of drugs. ${ }^{43}$ Infusion via a PVA has been validated by the authors of this and other studies. Side effects are scarce and, if any, they develop 6 hours after infusion. ${ }^{1}$ Side effects may be prevented by diluting vasoactive drugs 10 times more than when administered via a CVC. ${ }^{1,44-51}$

Adrenaline is indicated for cold shock $(0.05 \mu \mathrm{g} / \mathrm{kg} / \mathrm{min}$ up to $0.3 \mu \mathrm{g} / \mathrm{kg} / \mathrm{min})$ in an attempt to optimize cardiac contractility due to its beta-agonist effect at these dose ranges. For warm shock, alpha agonists $(0.1 \mu \mathrm{g} / \mathrm{kg} / \mathrm{min}$ and higher doses) are recommended. Dopamine is associated with a higher mortality compared to adrenaline and noradrenaline, and is reserved as a second-line choice. ${ }^{52-56}$ Other vasoactive drugs may be used looking for specific hemodynamic effects: inotropes, such as milrinone, to improve contractility, or vasopressors, like vasopressin, in case of vasodilation uncontrolled with noradrenaline (Tables 2 and 3).

\section{STABILIZATION BUNDLE (GENERALLY AFTER 60 MINUTES)}

A lack of response to the initial resuscitation measures requires invasive monitoring and ICU- relevant management that exceed the objectives of this study. Until a patient is transferred to the ICU, a goal-directed treatment should be followed.

Objectives include the following: ${ }^{1}$

- Normal perfusion, normal HR for age.

- Adequate TPP/APP for age.

- $\mathrm{ScvO}_{2}>70 \%$.

- Optimized mechanical ventilation.

Actions should include the following:

- Complement initial monitoring with basic invasive monitoring (continuous intra-arterial blood pressure, central venous pressure, and $\mathrm{ScvO}_{2}$ ).

- Monitor for the development of compartmental syndrome and pneumothorax, and treat them.

- Titrate glucose, calcium, lactate, anion gap, and hematocrit levels and coagulation profile.

- Adjust the administration of fluids, vasoactive drugs, and hormones based on multimodal monitoring.

- Control the source of infection (collection drainage, etc.).

\section{REFERRAL BUNDLE}

Teams specialized in critical care and rapid response, which have been recently developed, have reduced mortality and improved the clinical course of SS. ${ }^{57,58}$ If sepsis is suspected in a child, trained staff, such as pediatric emergency physicians, pediatric intensivists or pediatric hospitalists, should be consulted about an adequate and timely treatment. If the patient does not respond in the first hour after initial resuscitation, he/she should be seen by a specialist. $^{4}$

Telemedicine (remote consultation using IT devices, such as mobile phones, computers, etc.) allows an expert to "virtually and distally see" a patient who is at a facility with a lower level of care. It is relatively simple, more accurate than a telephone consultation, more comfortable for the health care provider at facilities with a lower level of care, and improves processes and reduces costs. ${ }^{59-62}$ In the province of San Luis, Argentina, positive results were reported using this modality. ${ }^{63}$

\section{OUTCOME MEASUREMENT BUNDLE}

Different studies have reported care process improvements after the implementation of this bundle. ${ }^{1,5,64-67}$

In New York, USA, hospitals are required to develop sepsis protocols focused on early 
recognition and treatment, implement them, and report results to the government and the community. ${ }^{68}$

The following measurements are recommended:

- Bundle adherence.

- Achievement of goals.

- Barrier description.
- Observed unwanted effects.

- Adherence to antibiotic administration in the first hour.

\section{OTHER THERAPEUTIC CONSIDERATIONS Hormonal therapy}

These children may require hormonal therapy, although there is no agreement in this regard. ${ }^{1,69-72}$

TABLE 2. Vasoactive drugs used in cold septic shock in the first hours in children ${ }^{1,77,78}$

\begin{tabular}{|c|c|c|c|c|}
\hline & & Cold shock & & \\
\hline Drug & Dose & Receptor & Effect & Remarks \\
\hline Adrenaline & $\begin{array}{c}\text { Initial: } \\
\text { 0.05- } 0.3 \mu \mathrm{g} / \mathrm{kg} / \mathrm{min} \\
\text { Treatment: } \\
\text { Titrate for inotrope doses } \\
\text { Up to } 0.3 \mu \mathrm{g} / \mathrm{kg} / \mathrm{min} \\
\text { For inoconstrictor doses } \\
0.4-0.8 \mu \mathrm{g} / \mathrm{kg} / \mathrm{min} \\
\text { Objective: Stimulate } \\
B 1 \text { and } B 2 \text { receptors }\end{array}$ & $\alpha_{1^{\prime}} \alpha_{2^{\prime}}, \beta_{1^{\prime}}, \beta_{2}$ & $\begin{array}{c}\uparrow \text { Inotropism } \\
\left(\beta_{1}\right) \\
\uparrow \text { Chronotropism }\left(\beta_{2}\right) \\
\text { Arterial and venous } \\
\text { vasoconstriction }\left(\alpha_{1}\right) \\
\text { Arterial vasodilatation } \\
\beta_{2}\end{array}$ & $\begin{array}{c}\text { Dilute } 10 \text { times for } \\
\text { peripheral or intraosseous } \\
\text { access or indicate } \\
\text { other parallel infusion } \\
\text { for dilution. } \\
\text { Dose: }>0.3 \mu \mathrm{g} / \mathrm{kg} / \mathrm{min} \text { : } \\
\text { Risk for renal ischemia, } \\
\text { myocardial ischemia, and } \\
\text { pulmonary hypertension. }\end{array}$ \\
\hline Dopamine & $\begin{array}{c}\text { Initial: } \\
5-9 \mu \mathrm{g} / \mathrm{kg} / \mathrm{min} \\
\text { Treatment: } \\
\text { Titrate for inotrope doses } \\
\text { Up to } 15 \mu \mathrm{g} / \mathrm{kg} / \mathrm{min} \\
\text { Titrate for } \\
\text { vasopressor doses } \\
>15 \mu \mathrm{g} / \mathrm{kg} / \mathrm{min}\end{array}$ & $\alpha_{1}, \alpha_{2}, \beta_{1}, \mathrm{DA}_{1}$ & $\begin{array}{c}\uparrow \text { Inotropism }\left(\beta_{1}\right) \\
\uparrow \text { Chronotropism }\left(\beta_{2}\right) \\
\text { Arterial and venous } \\
\text { vasoconstriction }\left(\alpha_{1}\right)\end{array}$ & $\begin{array}{c}\text { Greater mortality than } \\
\text { with adrenaline and / or } \\
\text { noradrenaline. }\end{array}$ \\
\hline Dobutamine & $\begin{array}{c}\text { Initial: } \\
10 \mu \mathrm{g} / \mathrm{kg} / \mathrm{min} \\
\text { Treatment: } \\
\text { Titrate for inotrope doses } \\
\text { Up to } 20 \mu \mathrm{g} / \mathrm{kg} / \mathrm{min} \\
\end{array}$ & $\beta_{1^{\prime}} \beta_{2}$ & $\begin{array}{c}\uparrow \text { Inotropism } \\
\left(\beta_{1}\right) \\
\uparrow \text { Chronotropism } \\
\text { Minimum effect } \beta_{2}\end{array}$ & \\
\hline Milrinone & $\begin{array}{c}\text { Initial: } \\
\text { Assess load at } \\
50 \mu \mathrm{g} / \mathrm{kg} \text { in } 15 \mathrm{~min} \\
\text { Treatment: } \\
\text { Titrate for inotrope doses } \\
0.25-0.75 \mu \mathrm{g} / \mathrm{kg} / \mathrm{min}\end{array}$ & $\begin{array}{l}\text { Phosphodiesterase } \\
\text { inhibitor } \\
\text { Increases } \\
\text { cyclic adenosine } \\
\text { monophosphate }\end{array}$ & $\begin{array}{c}\uparrow \text { Inotropism } \\
\text { Arterial vasodilation }\end{array}$ & $\begin{array}{c}\text { Acts in a synergistic } \\
\text { manner with } \\
\beta \text {-adrenergic } \\
\text { receptors. }\end{array}$ \\
\hline $\begin{array}{l}\text { Inamrinone } \\
\text { (formerly } \\
\text { amrinone) }\end{array}$ & $\begin{array}{c}\text { Treatment: } \\
\text { Titrate for } \\
\text { inotrope doses at } \\
5-10 \mu \mathrm{g} / \mathrm{kg} / \mathrm{min}\end{array}$ & $\begin{array}{c}\text { Phosphodiesterase } \\
\text { inhibitor } \\
\text { Increases } \\
\text { cyclic adenosine } \\
\text { monophosphate } \\
\end{array}$ & $\begin{array}{c}\uparrow \text { Inotropism } \\
\text { Arterial } \\
\text { vasodilation }\end{array}$ & $\begin{array}{l}\text { Acts in a synergistic } \\
\text { manner with } \\
\beta \text {-adrenergic } \\
\text { receptors. }\end{array}$ \\
\hline Levosimendan & $\begin{array}{c}\text { Treatment: } \\
\text { Current trend } \\
\text { Single dose via continuous } \\
\text { perfusion over } 24 \mathrm{~h} \\
\text { at } 0.2 \mu \mathrm{g} / \mathrm{kg} / \mathrm{min} \\
\text { (total maximum } \\
\text { dose of } 12.5 \mathrm{mg} \text { ) }\end{array}$ & $\begin{array}{c}\text { Increases } \\
\text { Ca++/actin/ } \\
\text { tropomyosin binding } \\
\text { Lower } \\
\text { phosphodiesterase } \\
\text { inhibitory activity }\end{array}$ & $\uparrow$ Inotropism & \\
\hline Nitroglycerin & $\begin{array}{c}\text { Treatment: } \\
0.5-10 \mu \mathrm{g} / \mathrm{kg} / \mathrm{min}\end{array}$ & & Venous vasodilation & \\
\hline Nitroprusside & $\begin{array}{c}\text { Treatment: } \\
0.2-6 \mu \mathrm{g} / \mathrm{kg} / \mathrm{min}\end{array}$ & & $\begin{array}{l}\text { Arterial and venous } \\
\text { vasodilation }\end{array}$ & $\begin{array}{c}\text { Toxicity caused by } \\
\text { thiocyanate }\end{array}$ \\
\hline
\end{tabular}

$\mu \mathrm{g} / \mathrm{kg} / \mathrm{min}$ : microgram/kilogram/minute; mg: milligram; $\alpha_{1}, \alpha_{2}$ : alpha 1 and alpha $2 ; \beta_{1}$ and $\beta_{2}$ : beta 1 and beta 2; $\mathrm{Ca}++$ : ionic calcium; $\mathrm{DA}_{1}$ : dopamine receptor antagonist. 
Hydrocortisone is suggested only in children with catecholamine-refractory septic shock and/ or suspected or proven adrenal insufficiency. Patients receiving prolonged corticosteroid treatment, with central nervous system diseases and/or alterations in adrenocorticotropic hormone $(\mathrm{ACTH})$ production or purpura fulminans who do not respond to vasoactive drugs are at a higher risk for adrenal insufficiency. In adults, low doses are effective (hydrocortisone $100 \mathrm{mg} / \mathrm{m}^{2} /$ day in 4 doses). In children, an initial dose of $2 \mathrm{mg} / \mathrm{kg}$, followed by $1 \mathrm{mg} / \mathrm{kg}$ every 8 hours, is recommended. 73,74

Hypothyroidism may appear as a clinical presentation after the administration of corticosteroids and should be recognized and treated promptly. ${ }^{1}$

\section{Blood and blood products}

Although some previous recommendations established to set a target hemoglobin value higher than $10 \mathrm{~g} / \mathrm{dL}$, the current evidence suggests conservative targets for blood transfusion in critically-ill children without cardiopulmonary involvement and reserves its indication if hemoglobin is lower than $7 \mathrm{~g} / \mathrm{dL} .{ }^{75,76}$ Children with SS and severe anemia (hemoglobin $<6 \mathrm{~g} / \mathrm{dL}$ ) require more transfusions than fluids. Moreover, fluids may worsen anemic shock. ${ }^{31}$

Children with clinical signs of disseminated intravascular coagulation or purpura fulminans and active bleeding should receive fresh frozen plasma and blood products. ${ }^{1,4}$
In pediatrics, there are no recommendations for platelet transfusion in children with SS. It is suggested to transfuse less than 5000 platelets / $\mathrm{dL}$ if there is bleeding or risk for any procedure.

\section{CONCLUSIONS}

SS management requires a series of measures, starting with recognition, which triggers the timely administration of time-sensitive treatments.

Limitations in some areas where the initial measures are taken require a consultation with a specialist and/or an optimal referral to a facility with a higher level of care.

It is very important to assess these processes in order to improve the quality of care for children with sepsis; and the health care team, facilities in particular and governments in general should all become involved.

\section{Acknowledgments}

We would like to thank Mirta Susana Rodríguez, M.D., for reviewing our work and her valuable contributions.

\section{REFERENCES}

1. Davis AL, Carcillo JA, Aneja RK, et al. American College of Critical Care Medicine Clinical Practice Parameters for Hemodynamic Support of Pediatric and Neonatal Septic Shock. Crit Care Med. 2017; 45(6):1061-93.

2. Jabornisky R, Mansur A. Shock. Sociedad Argentina de Pediatría. PRONAP. 2013; 1:81-109.

3. Kohn Loncarica GA. Soporte hemodinámico precoz en el shock séptico. Arch Argent Pediatr. 2010; 108(3):249-54.

4. National Institute for Health and Care Excellence.

TABLE 3. Vasoactive drugs used in warm septic shock in children ${ }^{1,77,78}$

\begin{tabular}{|c|c|c|c|c|}
\hline \multicolumn{5}{|c|}{ Warm shock } \\
\hline Drug & Dose & Receptor & Effect & Remarks \\
\hline Noradrenaline & $\begin{array}{c}\text { Initial: } \\
0.05 \mu \mathrm{g} / \mathrm{kg} / \mathrm{min} \\
\text { Treatment: Titrate for } \\
\text { vasopressor doses } \\
\text { Target: stimulate } \\
\alpha_{1} \text { receptors }\end{array}$ & $\begin{array}{c}\alpha_{1} \\
\text { Mild effect on } \beta_{1} \\
\text { No effect on } \alpha_{2}\end{array}$ & $\begin{array}{c}\text { Vasoconstriction } \\
\text { Mild inotropism } \\
\uparrow \text { Mild chronotropism }\end{array}$ & $\begin{array}{c}\text { Dilute } 10 \text { times for peripheral } \\
\text { or intraosseous access } \\
\text { or use other parallel } \\
\text { infusion for dilution. } \\
\text { Sensibility does not depend } \\
\text { on age. }\end{array}$ \\
\hline Dopamine & $\begin{array}{c}\text { Initial: } \\
>10 \mu \mathrm{g} / \mathrm{kg} / \mathrm{min} \\
\text { Treatment: } \\
\text { Titrate for vasopressor doses } \\
>15 \mu \mathrm{g} / \mathrm{kg} / \mathrm{min} \\
\end{array}$ & $\alpha_{1}, \alpha_{2}, \beta_{1}$ & $\begin{array}{c}\uparrow \begin{array}{c}\text { Inotropism } \\
\left(\beta_{1}\right)\end{array} \\
\uparrow \text { Chronotropism }\left(\beta_{2}\right) \\
\text { Arterial and venous } \\
\text { vasoconstriction }\left(\alpha_{1}\right)\end{array}$ & $\begin{array}{c}\text { Greater mortality than with } \\
\text { adrenaline and/or noradrenaline. }\end{array}$ \\
\hline Vasopressin & $\begin{array}{c}\text { Treatment: } \\
\text { Titrate for vasopressor } \\
\text { doses } 0.0003-0.008 \mathrm{U} / \mathrm{kg} / \mathrm{min}\end{array}$ & $\mathrm{v}_{1 \mathrm{a}^{\prime}} \mathrm{v}_{1 \mathrm{~b}^{\prime}}$ and $\mathrm{v}_{2}$ & $\begin{array}{c}\text { Arterial } \\
\text { vasoconstriction }\end{array}$ & \\
\hline
\end{tabular}

$\mu \mathrm{g} / \mathrm{kg} / \mathrm{min}$ : microgram $/$ kilogram / minute; $\mathrm{U} / \mathrm{kg} / \mathrm{min}$ : unit $/$ kilogram $/$ minute; $\alpha_{1}, \alpha_{2}$ : alpha 1 and alpha 2;

$\beta_{1}$ and $\beta_{2}$ : beta 1 and beta $2 ; v_{1 a^{\prime}} v_{1 b^{\prime}}$ and $v_{2}$ : vasopressin receptors $1 \mathrm{a}, 1 \mathrm{~b}$, and 2 . 
Sepsis: Recognition, Diagnosis and Early Management. National Guideline Centre. London. 2016;51. [Accessed on: November $\left.30^{\text {th }}, 2017\right]$. Available at: https://www.nice. org.uk/guidance/ng51/ resources / sepsis-recognitiondiagnosis-and-early-management-pdf-1837508256709.

5. Rhodes A, Evans LE, Alhazzani W, et al. Surviving Sepsis Campaign: International Guidelines for Management of Sepsis and Septic Shock: 2016. Intensive Care Med. 2017; 43(3):304-77.

6. Ministerio de Salud. Síndrome Bronquial Obstructivo en niños menores de 2 años. Flujograma de decisión terapéutica según puntaje clínico de Tal (con frecuencia cardíaca). [Accessed on: November 30 $30^{\text {th }}, 2017$ ]. Available at: http://www.msal.gob.ar/images/stories/bes/ graficos / $0000000260 \mathrm{cnt}$-original-algoritmo-sbo-0-2anos-2018.pdf.

7. Ministerio de Salud. Síndrome Bronquial Obstructivo en niños de 2 a 5 años. Algoritmo de tratamiento de la crisis. [Accessed on: November 30 ${ }^{\text {th }}, 2017$ ]. Available at: http://www.msal.gob.ar/images/stories/bes/ graficos / $0000000261 \mathrm{cnt}$-original-algoritmo-sbo-2-5anos-2018.pdf.

8. Han YY, Carcillo JA, Dragotta MA, et al. Early reversal of pediatric-neonatal septic shock by community physicians is associated with improved outcome. Pediatrics. 2003; 112(4):793-9.

9. Carcillo J, Kuch B, Han YY, et al. Mortality and functional morbidity after use of PALS/APLS by community physicians. Pediatrics. 2009; 124(2):500-8.

10. Kumar R, Singhi S, Singhi P, et al: Randomized controlled trial comparing cerebral perfusion pressure-targeted therapy versus intracranial pressure-targeted therapy for raised intracranial pressure due to acute CNS infections in children. Crit Care Med. 2014; 42(8):1775-87.

11. Haque IU, Zaritsky AL. Analysis of the evidence for the lower limit of systolic and mean arterial pressure in children. Pediatr Crit Care Med. 2007; 8(2):138-44.

12. Yasaka Y, Khemani RG, Markovitz BP. Is Shock Index Associated With Outcome in Children With Sepsis/Septic Shock? Pediatr Crit Care Med. 2013; 14(8):e372-9.

13. Berger T, Green J, Horeczko T, et al. Shock index and early recognition of sepsis in the emergency department: pilot study. West J Emerg Med. 2013; 14(2):168-74.

14. CarcilloJA, Han K, Lin J, Orr R. Goal-Directed Management of Pediatric Shock in the Emergency Department. Clin Pediatr Emerg Med. 2007; 8(3):165-75.

15. Han YY, Carcillo JA, Espinosa V, Kissoon N. Quality improvement analysis of the global pediatricsepsis initiative registry simplified clinical bundle recommendations for industrialized developing and developed nations. Pediatr Crit Care Med. 2014; 15(Suppl 4):15-6.

16. Ceneviva G, Paschall J, Maffei F, CarcilloJA. Hemodynamic support in fluid-refractory pediatric septic shock. Pediatrics. 1998; 102(2):e19.

17. DeOliveira CF, deOliveiraDS, Gottschald AF, etal.ACCM/ PALS haemodynamic support guidelines for paediatric septic shock: An outcomes comparison with and without monitoring central venous oxygen saturation. Intensive Care Med. 2008; 34(6):1065-75.

18. Rivers E, Nguyen B, Havstad S, et al. Early Goal-Directed Therapy in the Treatment of Severe Sepsis and SepticShock. N Engl J Med. 2001; 345(19):1368-77.

19. Cam BV, Tuan DT, Fonsmark L, et al. Randomized comparison of oxygen mask treatment vs nasal continuous positive airway pressure in dengue shock syndrome with acute respiratory failure. J Trop Pediatr. 2002; 48(6):335-59.

20. Kohn Loncarica G, Fustiñana A, Pavlicich V, et al. Especialidad en urgencias pediátricas: calidad en atención de niñõs con shock séptico en servicios de urgencias de Latinoamérica. Presentación oral larga en la 23 Reunión Anual de la Sociedad Española de Urgencias de Pediatría. Sitges, España, 21 de abril de 2018. [Accessed on: July $3^{\text {rd }}$, 2018]. Available at: https://seup.org/pdf_public/ reuniones / 2018/COL/ col21_008.pdf

21. [Banerjee S, Singhi SC, Singh S, Singh M. The intraosseous route is a suitable alternative to intravenous route for fluid resuscitation in severely dehydrated children. Indian Pediatr. 1994; 31(12):1511-20.

22. Lamperti M, Caldiroli D, Cortellazzi P, et al. Safety and efficacy of ultrasound assistance during internal jugular vein cannulation in neurosurgical infants. Intensive Care Med. 2008; 34(11):2100-5.

23. National Institute for Clinical Excellence: Guidance on the Use of Ultrasound Locating Devices for Placing Central Venous Catheters. 2002;49. [Accessed on: January 15 2018]. Available at: https://www.nice.org.uk/guidance/ ta49/ resources / guidance-on-the-use-of-ultrasoundlocating-devices-for-placing-central-venous-catheterspdf-2294585518021.

24. Hoban LD, Paschall JA, Eckstein J, et al. Awake porcine model of intraperitoneal sepsis and altered oxygen utilization. Circ Shock. 1991; 34(2):252-62.

25. Dung NM, Day NP, Tam DT, et al. Fluid replacement in dengue shock syndrome: A randomized, double-blind comparison of four intravenous-fluid regimens. Clin Infect Dis. 1999; 29(4):787-94.

26. Long E, Babl F, Dalziel S, et al. Fluid resuscitation for paediatric sepsis: A survey of senior emergency physicians in Australia and New Zealand. Emerg Med Australas. 2015; 27(3):245-50.

27. Carcillo JA. Intravenous fluid choices in critically ill children. Curr Opin Crit Care. 2014; 20(4):396-401.

28. Corrêa TD, Cavalcanti AB, Assunção MS. Balanced crystalloids for septic shock resuscitation. Rev Bras Ter Intensiva. 2016; 28(4):463-71.

29. Corrêa TD, Rocha LL, Pessoa CM, et al. Fluid therapy for septic shock resuscitation: which fluid should be used? Einstein (Sao Paulo). 2015; 13(3):462-8.

30. Mendes PV,Zampieri FG, ParkM. Is there a role for balanced solutions in septic patients? Shock. 2017; 47(1 Suppl 1):304.

31. Maitland K, Kiguli S, Opoka RO, et al. Mortality after Fluid Bolus in African Children with Severe Infection. $N$ Engl J Med. 2011; 364(26):2483-95.

32. Hoste EA, Maitland K, Brudney CS, et al. Four phases of intravenous fluid therapy: a conceptual model. BrJ Anaesth. 2014; 113(5):740-7.

33. Wheeler D. Is the "golden age" of the "golden hour" in sepsis over? Crit Care. 2015; 19:447.

34. Sankar J, Ismail J, Sankar MJ, et al. Fluid Bolus Over 15-20 Versus 5-10 Minutes Each in the First Hour of Resuscitation in Children With Septic Shock: A Randomized Controlled Trial. Pediatr Crit Care Med. 2017; 18(10):e435-45.

35. Weiss SL, Fitzgerald JC, Balamuth F, et al. Delayed Antimicrobial Therapy Increases Mortality and Organ Dysfunction Duration in PediatricSepsis. Crit Care Med.2014; 42(11):2409-17.

36. Wang XD, Huo XM, Xu MX, et al. Clinical research of timing of application of antibiotics in septic shock of pediatric patients. ZhonghuaWeiZhong Bing JiJiu Yi Xue. 2013;25(4):20710.

37. ZubertS, FunkDJ, KumarA. Antibiotics in sepsis and septic shock: like everything else in life, timing is everything. Crit Care Med. 2010; 38(4):1211-2.

38. Kumar A, Roberts D, Wood KE, et al. Duration of hypotension before initiation of effective antimicrobial 
therapy is the critical determinant of survival in human septic shock. Crit Care Med. 2006; 34(6):1589-96.

39. Kumar A, Zarychanski R, Light B, et al. Early combination antibiotic therapy yields improved survival compared with monotherapy in septic shock: a propensity-matched analysis. Crit Care Med. 2010; 38(9):1773-85.

40. Branco RG, García PC, Piva JP, et al. Glucose level and risk of mortality in pediatric septic shock. Pediatr Crit Care Med. 2005; 6(4):470-2.

41. Cooper DJ, Walley KR, Wiggs BR, Russell JA. Bicarbonate does not improve hemodynamics in critically ill patients who have lactic acidosis. A prospective, controlled clinical study. Ann Intern Med. 1990; 112(7):492-8.

42. Mathieu D, Neviere R, Billard V, et al. Effects of bicarbonate therapy on hemodynamics and tissue oxygenation in patients with lactic acidosis: a prospective, controlled clinical study. Crit Care Med. 1991; 19(11):1352-6.

43. Inwald DP, Tasker RC, Peters MJ, et al. Emergency management of children with severe sepsis in the United Kingdom: the results of the Paediatric Intensive Care Society sepsis audit. Arch Dis Child. 2009; 94(5):348-53.

44. Turner DA, Kleinman ME. The use of vasoactive agents via peripheral intravenous access during transport of critically III infants and children. Pediatr Emerg Care. 2010; 26(8):5636.

45. Lampin ME, Rousseaux J, Botte A, et al. Noradrenaline use for septic shock in children: doses, routes of administration and complications. Acta Paediatr. 2012; 101(9):e426-30.

46. Ricard JD, Salomon L, Boyer A, et al. Central or peripheral catheters for initial venous access of ICU patients: a randomized controlled trial. Crit Care Med. 2013;41(9):210815.

47. Fustiñana A, Kohn Loncarica G, Latella A, et al. Seguridad y efectividad en el uso de inotrópicos administrados por acceso venoso periférico en una cohorte de pacientes pediátricos con diagnóstico shock séptico. $7 .^{\circ}$ Congreso Argentino de Emergencias y Cuidados Críticos en Pediatría. 10-13 de septiembre de 2014. San Miguel de Tucumán: Sociedad Argentina de Pediatría. 2014; PO6: 51. [Accessed on: January $\left.15^{\text {th }}, 2018\right]$. Available at: http:/ / www.sap.org. ar/docs / congresos/2014/emergencias / trabajos_libres. pdf.

48. Loubani OM, Green RS. A systematic review of extravasation and local tissue injury from administration of vasopressors through peripheral intravenous catheters and central venous catheters. J Crit Care. 2015; 30(3):653. e9-17.

49. Cardenas-García J, Schaub KF, Belchikov YG, et al. Safety of peripheral intravenous administration of vasoactive medication. J Hosp Med. 2015; 10(9):581-5.

50. Lewis T, Merchan C, Altshuler D, Papadopoulos J. Safety of the Peripheral Administration of Vasopressor Agents. J Intensive Care Med. 2017;1:885066616686035.

51. Hualde G, Rino P, Fustiñana A, et al. ¿Se pueden administrar drogas vasoactivas a través de un acceso venoso periférico en pacientes críticos? $8 .^{\circ}$ Congreso Argentino de Emergencias y Cuidados Críticos en Pediatría. 26-28 de abril de 2017. Buenos Aires: Sociedad Argentina de Pediatría, 2017; PO114:47. [Accessed on:January $15^{\text {th }}$, 2017]. Available at: http://www.sap.org.ar/uploads/archivos/files_resumenesemergencias-y-cuidados-criticos_1494452169.pdf.

52. Dellinger RP, Levy MM, Rhodes A, et al. Surviving Sepsis Campaign: International Guidelines for Management of Severe Sepsis and Septic Shock: 2012. Crit Care Med. 2013; 41(2):580-637.

53. Ventura AMC, Shieh HH, Bousso A, et al. Double-Blind Prospective Randomized Controlled Trial of Dopamine Versus Epinephrine as First-Line Vasoactive Drugs in
Pediatric Septic Shock. Crit Care Med. 2015; 43(11):2292302.

54. Ramaswamy KN, Singhi S, Jayashree M, et al. DoubleBlind Randomized Clinical Trial Comparing Dopamine and Epinephrinein PediatricFluid-Refractory Hypotensive Septic Shock. Pediatr Crit Care Med. 2016; 17(11):e502-12.

55. Sandifer JP, Jones AE. Dopamine versus norepinephrine for the treatment of septic shock EBEM commentators. Ann Emerg Med. 2012; 60(3):372-3.

56. De Backer D, Aldecoa C, Njimi H, Vincent JL. Dopamine versus norepinephrine in the treatment of septic shock: A meta-analysis. Crit Care Med. 2012; 40(3):725-30.

57. Ninis N, Phillips C, Bailey L, et al. The role of healthcare delivery in the outcome of meningococcal disease in children: case-control study of fatal and non-fatal cases. BMJ. 2005; 330(7506):1475.

58. Rosenthal JL, Kissee JL, Marcin JP. To See or Not to See: Telemedicine's Impact on Triage Outcomes. Pediatr Crit Care Med. 2017; 18(11):1081-3.

59. Harvey JB, Yeager BE, Cramer C, et al. The Impact of Telemedicine on Pediatric Critical Care Triage. Pediatr Crit Care Med. 2017; 18(11):e555-60.

60. Dharmar M, Romano PS, Kuppermann N, et al. Impact of critical care telemedicine consultations on children in rural emergency departments. Crit Care Med. 2013; 41(10):2388- 95.

61. Gattu R, Teshome G, Lichenstein R. Telemedicine applications for the pediatric emergency medicine: A review of the current literature. Pediatr Emerg Care. 2016; 32(2):123-30.

62. Pannu J, Sanghavi D, Sheley T, et al: Impact of telemedicine monitoring of community ICUs on interhospital transfers. Crit Care Med. 2017; 45(8):1344-51.

63. Pujales G. Organización de un sistema de transporte de pacientes críticos. Mesa Redonda: Abordaje del niño y sus familias en situación de desastres. $8{ }^{\circ}$ Congreso Argentino de Emergencias y Cuidados Críticos en Pediatría. 26-28 de abril de 2017. Buenos Aires: Sociedad Argentina de Pediatría, 2017; E 155.

64. Cruz AT, Perry AM, Williams EA, et al. Implementation of goal-directed therapy for children with suspected sepsis in the emergency department. Pediatrics. 2011; 127(3):e758-66.

65. Larsen GY, Mecham N, Greenberg R. An emergency department septic shock protocol and care guideline for children initiated at triage. Pediatrics. 2011; 127(6):e158592.

66. Paul R, Neuman MI, Monuteaux MC, Melendez E. Adherence to PALSSepsis Guidelines and Hospital Length of Stay. Pediatrics. 2012; 130(2):e273-80.

67. Paul R, Melendez E, Stack A, et al. Improving adherence to PALS septic shockguidelines. Pediatrics. 2014;133(5):e135866.

68. New York State. Department of Health. New York State Report on Sepsis Care Improvement Initiative: Hospital Quality Performance. New York. 2017. [Accessed on: January $\left.15^{\text {th }}, 2018\right]$. Available at: https://www.health. ny.gov/press/reports/docs/2015_sepsis_care_improvement_ initiative.pdf.

69. Menon K, Wong HR. Corticosteroids in Pediatric Shock: A Call to Arms. Pediatr Crit Care Med. 2015; 16(8):e313-7.

70. Menon K, McNally D, O'Hearn K, et al. A Randomized Controlled Trial of Corticosteroids in Pediatric Septic Shock: APilot Feasibility Study. Pediatr Crit Care Med. 2017; 18(6):505-12.

71. Joosten KF, de Kleijn ED, Westerterp M, et al. Endocrine and metabolic responses in children with meningoccocal sepsis: Striking differences between survivors and nonsurvivors. J Clin Endocrinol Metab. 2000; 85(10):3746-53.

72. O'Hearn K, McNally D, Choong K, et al. Steroids in fluid 
and/or vasoactive infusion dependent pediatric shock: study protocol for a randomized controlled trial. Trials. 2016; 17(1):238.

73. Menon K, McNally JD, Choong K, et al. A cohort study of pediatric shock: Frequency of corticosteroid use and association with clinical outcomes. Shock. 2015;44(5):402-9.

74. Menon K, McNally JD, Choong K, et al. A survey of stated physician practices and beliefs on the use of steroids in pediatric fluid and/or vasoactive infusion-dependent shock. Pediatr Crit Care Med. 2013; 14(5):462-6.

75. Karma O, Tucci M, Ducruet T, et al. Red blood cell transfusion thresholds in pediatric patients with sepsis. Pediatr Crit Care Med. 2011; 12(5):512-8.
76. Lacroix J, Tucci M, Du Pont-Thibodeau G. Red blood cell transfusion decision making in critically ill children. Curr Opin Pediatr. 2015; 27(3):286-91.

77. Muñoz Bonet JI, Roselló Millet P. Protocolo Fármacos Vasoactivos: Dosis, Indicaciones y Efectos Adversos. Madrid: Sociedad Española de Cuidados Intensivos Pediátricos. 2013. [Accessed on: January 15 ${ }^{\text {th }}$, 2018]. Available at: https://www. secip.com/publicaciones-relacionadas/protocolos/category/36fa-rmacos-vasoactivos-2013-fa-rmacos-vasoactivos-2013.

78. Hospital Garrahan. Vademecum. [Accessed on: January $\left.15^{\text {th }}, 2018\right]$. Available at: http://www.garrahan.gov.ar/ vademecum/alfabetico_nquimico.php. 